\title{
Vitamin D Supplementation in Pregnancy and Its Correlation with Fetomaternal Outcome
}

\author{
Vasundhara K, Swapna R*, Prasannalatha A and \\ Shruti K \\ Department of Obstetrics and Gynaecology, Kamineni \\ Academy of Medical Sciences and Research Centre, India \\ *Corresponding author: Rathlawath Swapna, \\ Department of Obstetrics and Gynaecology, Kamineni \\ Academy of Medical Sciences and Research Centre, \\ Assistant professor, India
}

Received: October 26, 2016; Accepted: January 05, 2017; Published: January 06, 2017

\author{
Abstract \\ Vitamin D is known as Sunshine vitamin which mainly helps in bone \\ metabolism. It is estimated that one billion people have vitamin $D$ deficiency and \\ it is considered as a public health problem.
}

Aim: To measure vitamin $D$ levels in $1^{\text {st }}$ trimester and reassess level of vitamin $D$ in $3^{\text {rd }}$ trimester after treatment. To evaluate its correlation with fetomaternal outcome.

Study Design: It is a prospective observational study of 100 pregnant women booked in the $1^{\text {st }}$ trimester and serum vitamin $\mathrm{D}$ level tested. Women who were found insufficient (vitamin $D$ level $<30 \mathrm{ng} / \mathrm{ml}$ ) were counseled and supplemented in second trimester. Serum vitamin $D$ is tested again in $3^{\text {rd }}$ trimester. Maternal complications and fetal outcome measured complications like preeclampsia and preterm birth recorded.

Observation and Results: In our study the mean vitamin $D$ level was $17.8 \pm 7.05 \mathrm{ng} / \mathrm{ml}$, vitamin D deficiency $(<20 \mathrm{ng} / \mathrm{ml})$ was seen in $69 \%$ females, insufficiency $(20-30 \mathrm{ng} / \mathrm{ml})$ in $24 \%$. Supplementation was done in 40 vitamin $D$ deficient women. The mean vitamin $D$ level in the $1^{\text {st }}$ trimester increased from $16.88 \pm 4.490$ to $30.02 \pm 5.767$ in third trimester ( $p$ value $=0.0001$ ). Among the females who were supplemented with vitamin $D$, only $1(2.5 \%)$ developed preeclampsia and $2(5 \%)$ females developed preterm birth.

Conclusion: The present study concludes that there is high prevalence of vitamin D deficiency in pregnancy. Vitamin D deficiency correlates with preeclampsia and preterm birth. Supplementation of vitamin $D$ is safe and it increases vitamin D levels significantly in $3^{\text {rd }}$ trimester as well as the birth weight of the fetus.

Keywords: Vitamin D supplementation; Preeclampsia; Preterm birth

\section{Introduction}

Vitamin D deficiency or insufficiency is currently a global pandemic affecting some one billion of all ages and ethnic groups [1]. Reports from developing and developed countries show high prevalence of vitamin D deficiency. Vitamin D is a fat soluble vitamin produced endogenously in the skin with exposure to sunlight. It is also obtained from consuming fortified milk or juice, fish oils, and dietary supplements of vitamin $\mathrm{D}$ that is ingested or produced in the skin must undergo hydroxylation in the liver to 25 hydroxyvitamin $\mathrm{D}$ $(25(\mathrm{OH}) \mathrm{D})$, then further hydroxylation primarily in the kidney to the physiologically active 1,25 dihydroxyvitamin $\mathrm{D}$. This active form is essential to promote absorption of calcium from the gut and enables normal bone mineralization and growth. The proportion of vitamin D obtained from diet is small as compared to that synthesized from skin in response to sunlight.

Recent evidence suggests that vitamin D deficiency is common during pregnancy especially among high risk groups, including vegetarians and women with limited sun exposure (eg. those who live in cold climate, resides in northern latitudes and wear sun and winter protective clothing) [2-4]. New born vitamin D levels are largely dependent on maternal vitamin D status. Consequently, infants of mothers with vitamin $\mathrm{D}$ deficiency are also at risk of vitamin D deficiency $[4,5]$.

Vitamin D intake is essential for maternal health and prevention of adverse outcomes [6]. Vitamin D deficiency is defined as a $25(\mathrm{OH})$ $\mathrm{D}$ below $20 \mathrm{ng} / \mathrm{ml}$ and vitamin D insufficiency as a $25(\mathrm{OH}) \mathrm{D}$ of 21-29 $\mathrm{ng} / \mathrm{ml}[7]$.

Preeclampsia and hypertensive disorders complicate 3-10\% of pregnancies and contribute to maternal and neonatal morbidity and mortality [8]. Several studies have shown that women with preeclampsia have lower urinary calcium excretion, lower ionized calcium levels, higher Parathormone (PTH) levels and lower 1,25 dihydroxyvitamin levels compared with normotensive pregnant control subjects [9]. Patients with 25(OH)D levels <15ng/ml have a 5 fold increase in the risk of preeclampsia, despite receiving prenatal vitamins [10]. Maternal vitamin D levels have been shown to positively correlate with birth weight centile [11]. Women with vitamin D deficiency have a 2.4 fold increased risk of having a small for gestational age baby [12]. Low vitamin $\mathrm{D}$ levels in late pregnancies were associated with reduced intrauterine long bone growth and lower gestational age at delivery [13].

Vitamin D is important to maternal health, fetal development 

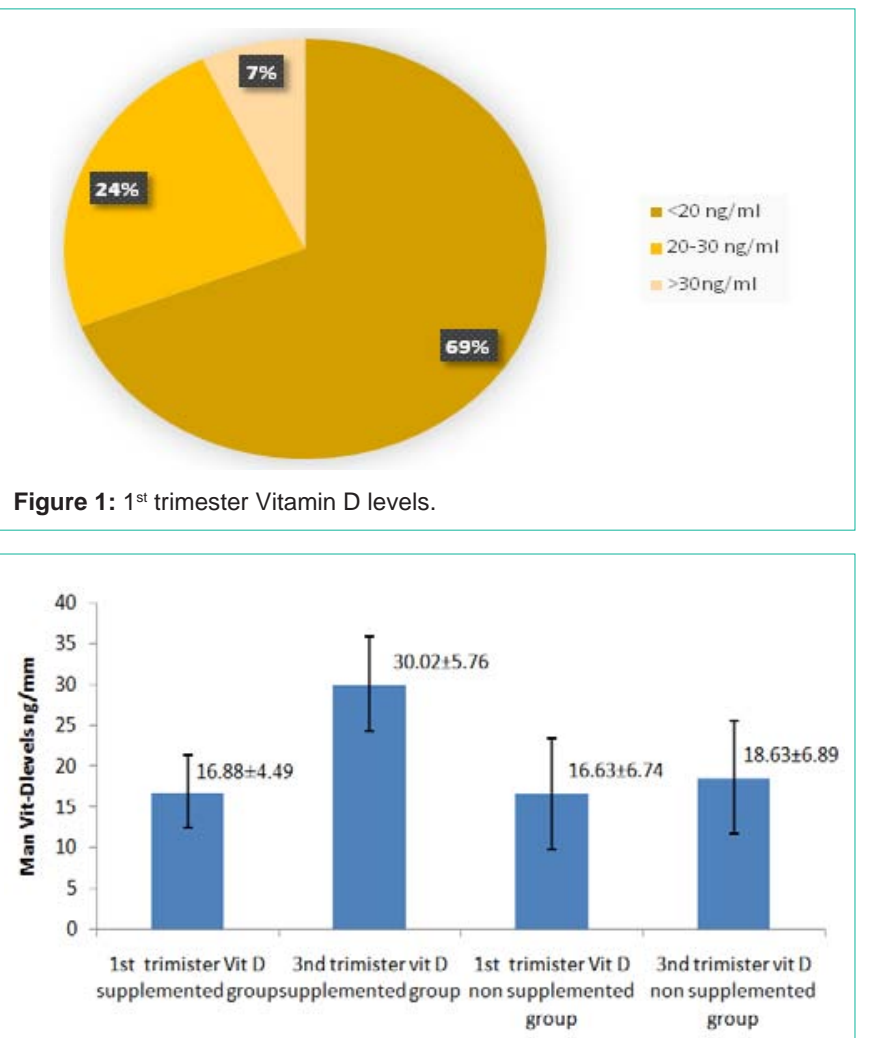

Figure 2: Mean vit-D levels in $1^{\text {st }}$ and $3^{\text {rd }}$ trimester.

and postnatal life. Current prenatal care does not include the monitoring of vitamin $\mathrm{D}$ levels. Though the current recommendation for vitamin D intake during pregnancy is $200-400 \mathrm{IU} / \mathrm{d}$, prenatal supplements that contain $400 \mathrm{IU}$ of vitamin D are not adequate to achieve normal vitamin $\mathrm{D}$ levels in pregnant women or their infants [14]. Supplementation of 800-1600 IU per day during last trimester in women with $25(\mathrm{OH}) \mathrm{D}<15 \mathrm{ng} / \mathrm{ml}$ showed increase in vitamin $\mathrm{D}$ levels $[15,16]$. Therefore, supplementation of vitamin $\mathrm{D}$ in doses that exceed $1000 \mathrm{IU}$ per day (2000-10000 IU/d) may be required to achieve a normal concentration of circulating vitamin D in severely deficient patients [17].

According to recent committee opinion of American College of Obstetrics and Gynaecology (ACOG), till now there is insufficient evidence to support a recommendation for screening all pregnant women for vitamin $\mathrm{D}$ deficiency. Also there is insufficient evidence to recommend vitamin $\mathrm{D}$ supplementation for the prevention of preterm birth and preeclampsia [18]. Thus in view of above cited evidences and persisting lacunae the current study was planned. In this study we assessed the vitamin D status of 100 consecutive females in $1^{\text {st }}$ and $3^{\text {rd }}$ trimester and observed for complications like preeclampsia and preterm birth.

The present study aims to measure vitamin D levels in $1^{\text {st }}$ trimester and reassess vitamin $\mathrm{D}$ levels in $3^{\text {rd }}$ trimester after treatment with 60000IU Cholecalciferol per week for 6 weeks was done in second trimester and to evaluate its correlation with fetomaternal outcome.

\section{Materials and Methods}

100 pregnant women attending antenatal clinic at Kamineni hospital L.B nagar, Hyderabad, India in the first trimester of pregnancy. Ethical committee approval taken from KAMS\&RC institution ethics committee.

\section{Inclusion criteria}

Pregnant women booked in first trimester of pregnancy.

\section{Exclusion criteria}

Pregnant women diagnosed with chronic kidney disease, chronic liver disease, known hyper parathyroid, malabsorption syndrome, women on antitubercular drugs, anti epileptics, steroids, known cases of diabetes mellitus.

\section{Study design}

It is a prospective observational study of 100 pregnant women, booked at antenatal clinic of Kamineni Hospital, in the first trimester. Detailed history, physical and obstetric examination was done in all subjects. Serum vitamin D levels were tested in first trimester of pregnancy. Women who were found deficient (vit $\mathrm{D}<20 \mathrm{ng} / \mathrm{ml}$ ) or insufficient (vit D 20-30 ng/ml) were counseled about the potential harms of vitamin D deficiency and supplementation, its benefits. Final choice for supplementation was left on the patient. Supplementation with 60000IU Cholecalciferol per week for 6 weeks was done in second trimester for vitamin D deficient women. Serum vitamin D was tested again in all subjects during third trimester. Observation for antenatal complications like preeclampsia and preterm birth was done and correlated to serum vitamin D levels. Serum vitamin D was assessed by using ELISA kit (IDS 250 vitamin D EIAKIT). Statistical analysis of data was conducted by using SPSS software (version 15.0; SPSS). Data presented as mean \pm SD. For categorical variables $t$ test was used and for comparison of percentages and proportions chisquare test was used, $\mathrm{p}$-value of $<0.05$ was considered significant.

\section{Results}

Mean age in the study was $25.62 \pm 4.04$ years. Mean vitamin D level was $17.8 \pm 7.05 \mathrm{ng} / \mathrm{ml}$. vitamin D deficiency $(<20 \mathrm{ng} / \mathrm{ml})$ was seen in $69 \%$ females, insufficiency $(20-30 \mathrm{ng} / \mathrm{ml})$ in $24 \%$ and sufficiency $(>30 \mathrm{ng} / \mathrm{ml})$ in $7 \%$ of pregnant women (Figure 1). Supplementation was done in 40 vitamin $\mathrm{D}$ deficient women. It increased mean vitamin D levels from $16.88 \pm 4.490$ to $30.02 \pm 5.767$ from first to third trimester ( $\mathrm{p}$ value $=0.0001$ ). Vitamin D levels in third trimester were significantly higher than first trimester even in 53 women who were deficient in vitamin $\mathrm{D}$, but not supplemented $(\mathrm{p}=0.0001)$ (Figure 2 , Table1,2). Preeclampsia developed in $14 \%$ women with mean first trimester vitamin D level of $12.43 \pm 3.435 \mathrm{ng} / \mathrm{ml}$ and third trimester vitamin D level of $14.00 \pm 5.009 \mathrm{ng} / \mathrm{ml}$ which were significantly lower than women not developing preeclampsia (mean vitamin $\mathrm{D}$ $18.68 \pm 7.107 \mathrm{ng} / \mathrm{ml}$ in first trimester and $26.11 \pm 8.048 \mathrm{ng} / \mathrm{ml}$ in third

Table 1: Distribution of cases according to supplementation status.

\begin{tabular}{|c|c|c|c|c|c|}
\hline & & \multicolumn{4}{|c|}{$1^{\text {stTrimesterVitD level }}$} \\
\hline & & $<20 \mathrm{ng} / \mathrm{ml}$ & $20-30 \mathrm{ng} / \mathrm{ml}$ & $>30 \mathrm{ng} / \mathrm{ml}$ & Total \\
\hline \multirow{4}{*}{ Supplementation } & \multirow{2}{*}{ YES } & 31 & 9 & 0 & 40 \\
\hline & & $77.50 \%$ & $22.50 \%$ & $0 \%$ & $100.00 \%$ \\
\hline & \multirow{2}{*}{ NO } & 38 & 15 & 7 & 60 \\
\hline & & $63.33 \%$ & $25.00 \%$ & $11.66 \%$ & $100.00 \%$ \\
\hline \multicolumn{2}{|l|}{ Total } & 69 & 24 & 7 & 100 \\
\hline
\end{tabular}


Table 2: $1^{\text {st }}$ and $3^{\text {rd }}$ trimester vitamin $D$ levels in 40 females having vitamin $D$ $<30 \mathrm{ng} / \mathrm{ml}$ who were supplemented and not supplemented.

\begin{tabular}{|c|c|c|c|c|c|}
\hline & & $\begin{array}{c}\text { Mean } \\
\text { Vit D } \\
\text { level (ng/ } \\
\text { ml) }\end{array}$ & $\mathrm{N}$ & $\begin{array}{c}\text { Std. } \\
\text { Deviation }\end{array}$ & $\begin{array}{c}\mathrm{P} \\
\text { Value }\end{array}$ \\
\hline \multirow{2}{*}{$\begin{array}{l}\text { Vit D supplemented } \\
\text { group }\end{array}$} & $\begin{array}{c}\text { 1stTrimester Vit } \\
\text { D level }\end{array}$ & 16.88 & 40 & 4.49 & \multirow{2}{*}{0.0001} \\
\hline & $\begin{array}{c}3^{\text {rd }} \text { Trimester Vit } \\
\text { D level }\end{array}$ & 30.02 & 40 & 5.767 & \\
\hline \multirow{2}{*}{$\begin{array}{c}\text { Vit D not } \\
\text { supplemented group }\end{array}$} & $\begin{array}{c}1^{\text {st }} \text { Trimester Vit } \\
\text { D level }\end{array}$ & 16.63 & 60 & 6.74 & \multirow{2}{*}{0.0001} \\
\hline & $\begin{array}{c}{ }^{\text {rd }} \text { Trimester Vit } \\
\text { D level }\end{array}$ & 18.63 & 60 & 6.69 & \\
\hline
\end{tabular}

Table 3: Correlation of $1^{\text {st }} \& 3^{\text {rd }}$ trimester Vitamin D levels with Preeclampsia \& Preterm birth.

\begin{tabular}{|c|c|c|c|c|c|c|}
\hline \multicolumn{2}{|c|}{ Vitamin D Levels } & $<20 \mathrm{ng} / \mathrm{ml}$ & $20-30 \mathrm{ng} / \mathrm{ml}$ & $>30 \mathrm{ng} / \mathrm{ml}$ & Total & $P$ Value \\
\hline \multicolumn{7}{|c|}{$1^{\text {stTrimesterVitD level }}$} \\
\hline \multirow{2}{*}{ Preeclampsia } & YES & 13 & 1 & 0 & 14 & 0.002 \\
\hline & NO & 56 & 23 & 7 & 86 & \\
\hline \multirow{2}{*}{ Preterm Birth } & YES & 22 & 1 & 0 & 23 & 0.0001 \\
\hline & NO & 47 & 23 & 7 & 77 & \\
\hline \multicolumn{7}{|c|}{$\begin{array}{l}3^{\text {rd }} \text { Trimester Vit D } \\
\text { level }\end{array}$} \\
\hline \multirow{2}{*}{ Preeclampsia } & YES & 13 & 1 & 0 & 14 & 0.0001 \\
\hline & NO & 22 & 32 & 31 & 85 & \\
\hline \multirow{2}{*}{ Preterm Birth } & YES & 22 & 1 & 0 & 23 & 0.0001 \\
\hline & NO & 13 & 32 & 31 & 76 & \\
\hline
\end{tabular}

trimester $)(\mathrm{p}$ value $=0.0001)$. Preterm birth developed in $23 \%$ of women with mean first trimester vitamin D levels of $12.43 \pm 3.31 \mathrm{ng} /$ $\mathrm{ml}$ and third trimester vitamin $\mathrm{D}$ of $14.43 \pm 3.740 \mathrm{ng} / \mathrm{ml}$ compared to first trimester mean vitamin $\mathrm{D}$ of $19.40 \pm 7.109 \mathrm{ng} / \mathrm{ml}$ and third trimester level of $27.41 \pm 7.537 \mathrm{ng} / \mathrm{ml}$ in those who did not develop preterm birth $(\mathrm{p}$ value $=0.0001)$ (Table 3$)$. Among the females who were supplemented with vitamin D, only $1(2.5 \%)$ developed preeclampsia compared to $13(21.6 \%)$ among the non-supplemented group. Similarly, in the vitamin D supplemented group only 2 (5\%) female's developed preterm birth compared to 21 (35\%) females in the non-supplemented group. The mean birth weight of women who were supplemented with vitamin D is $2.82 \mathrm{~kg}$ when compared to non supplemented group which is $2.52 \mathrm{~kg}$, and it is statistically significant ( $p$ value $=0.006)($ Table 4$)$.

\section{Discussion}

Despite the fact that daily prenatal vitamin $\mathrm{D}$ supplementation is advised and observed in most countries, an alarmingly high prevalence of vitamin D insufficiency has been demonstrated in nearly all populations studied [19-21]. There is a growing concern about the various adverse health impacts of vitamin $\mathrm{D}$ deficiency during pregnancy may have on mother as well as on fetus and later in life [6].

Prevalence of vitamin D deficiency depends on the definition of deficiency. Optimal serum levels during pregnancy are still undetermined and remain an area of active research. The discrepancy of different cut-offs in different studies leads to varied worldwide prevalence of vitamin D deficiency in pregnancy. However, results of current study are consistent with various other studies. Sachan et a1.
[19], in their study reported 66.7\% females had vitamin D level $<15 \mathrm{ng} /$ $\mathrm{ml}$ and $84 \%$ females had vitamin D level below cut-off of $22.5 \mathrm{ng} / \mathrm{ml}$. In another study done by Jain et al. [5], vitamin D deficiency $<15 \mathrm{ng} /$ $\mathrm{ml})$ was found in $81.1 \%$ mothers; and insufficiency $(15-20 \mathrm{ng} / \mathrm{ml})$ in an additional $11.6 \%$ mothers. Sahu et al. [23] measured $25(\mathrm{OH})$ $\mathrm{D}$ in 121 adolescent girls in a rural low socioeconomic community and 139 pregnant women in the second trimester. The age-adjusted community prevalence of vitamin D deficiency $(250 \mathrm{HD}<50 \mathrm{nmol} / \mathrm{l})$ in adolescent girls was $88.6 \%$. Seventy-four percent of pregnant women had vitamin D deficiency. Marwaha et al. [24] studied 541 apparently healthy women with uncomplicated, single, intrauterine gestation reporting in any trimester. Mean serum 25(OH)D of pregnant women was 23.2 (SD 12.2) nmol/l, hypovitaminosis D $(25(\mathrm{OH}) \mathrm{D}<50 \mathrm{nmol} / \mathrm{l})$ was observed in $96.3 \%$ of the subjects.

In current study, mean $1^{\text {st }}$ trimester vitamin $\mathrm{D}$ levels in 53 pregnant women who had vitamin D levels $<30 \mathrm{ng} / \mathrm{ml}$ and who refused for supplementation even after counseling were $16.636 \pm 6.745 \mathrm{ng} / \mathrm{ml}$. When reassessed in $3^{\text {rd }}$ trimester the mean vitamin $D$ levels in this subset were $18.6346 \pm 6.891 \mathrm{ng} / \mathrm{ml}$. Thus, even in females who were not supplemented, vitamin D levels in $3^{\text {rd }}$ trimester were significantly higher than the $1^{\text {st }}$ trimester vitamin $\mathrm{D}$ levels, with a $\mathrm{P}$ value $=0.0001$. However, the vitamin $\mathrm{D}$ level remained below the deficiency cut off level $(<20 \mathrm{ng} / \mathrm{ml})$.

The mean $1^{\text {st }}$ trimester vitamin $\mathrm{D}$ levels in 40 pregnant women who had vitamin $\mathrm{D}$ levels $<30 \mathrm{ng} / \mathrm{ml}$ and who accepted supplementation is $16.88 \pm 4.49 \mathrm{ng} / \mathrm{ml}$; they were supplemented with 60000 IU cholecalciferol per week for 6 weeks. On reassessment in $3^{\text {rd }}$ trimester, mean vitamin D levels were $30.02 \pm 5.76 \mathrm{ng} / \mathrm{ml}$. Thus, post supplementation vitamin $\mathrm{D}$ levels significantly increased $(\mathrm{p}=$ 0.0001 ). Out of these 40 females, 20 had $3^{\text {rd }}$ trimester vitamin $\mathrm{D}$ levels higher than $30 \mathrm{ng} / \mathrm{ml}$. Hollis BW et al. did a randomized, controlled trial in which women with a singleton pregnancy at 12 to 16 weeks gestation received 400,2000 , or 4000 IU of vitamin D per day until delivery. The mean $25(\mathrm{OH}) \mathrm{D}$ concentrations by group at delivery and 1 month before delivery were significantly different $(\mathrm{p}<0.0001)$, and the percent who achieved sufficiency was significantly different by group, greatest in 4000 -IU group $(\mathrm{p}<0.0001)$ [2]. According to Cochrane database systematic review [25], four trials with a total of 414 women reported the maternal vitamin D status at term. The results consistently showed that women who received vitamin D supplements had higher $25(\mathrm{OH}) \mathrm{D}$ concentrations than those women who received no intervention or a placebo. The response to supplementation was highly heterogeneous and ranged from 11.00 to $151.80 \mathrm{nmol} 25(\mathrm{OH}) \mathrm{D}$.

In current study, 14 women had preeclampsia during pregnancy, out of these $13 \mathrm{had} 1^{\text {st }}$ trimester vitamin D levels $<20 \mathrm{ng} / \mathrm{ml}$ and 1 had levels between $20-30 \mathrm{ng} / \mathrm{ml}$. The mean $1^{\text {st }}$ trimester vitamin $\mathrm{D}$ level in these 14 females was $12.43 \pm 3.435 \mathrm{ng} / \mathrm{ml}$ compared to $18.68 \pm 7.01 \mathrm{ng} /$ $\mathrm{ml}$ in females who had no preeclampsia. Mean ${ }^{3 \mathrm{rd}}$ trimester vitamin D levels in 14 females developing preeclampsia was $14.0 \pm 5.09 \mathrm{ng} / \mathrm{ml}$ compared to $26.11 \pm 8.04 \mathrm{ng} / \mathrm{ml}$ in rest of the females. Thus, females who had preeclampsia had much lower $1^{\text {st }}$ and $3^{\text {rd }}$ trimester vitamin $D$ levels as compared to rest of the females.

Bodnar LM et al. [10], conducted a nested case-control study and found that adjusted serum 25(OH)D concentrations in early 
Table 4: Comparison of Birth weight among the supplemented and not supplemented group.

\begin{tabular}{|c|c|c|c|c|c|}
\hline & $\begin{array}{c}\text { Vit D } \\
\text { supplementation }\end{array}$ & Number & Mean & Std. Deviation & P value \\
\hline \multirow{2}{*}{ Birth weight } & YES & 40 & 2.82 & 0.395 & \multirow{2}{*}{0.006} \\
\cline { 2 - 6 } & NO & 60 & 2.5 & 0.73 & \\
\hline
\end{tabular}

pregnancy were lower in women who subsequently developed preeclampsia compared with controls $[\mathrm{p}<0.01]$. There was a monotonic dose-response relation between serum 25(OH)D concentrations at less than 22wk and risk of preeclampsia. Baker AM et al. [26] and Robinson CJ et al. [11], also found that decreased maternal 25-hydroxyvitamin D was significantly associated with diagnosis of early onset severe preeclampsia.

In present study, preterm birth was seen in 23 pregnancies, out of these 22 had $1^{\text {st }}$ trimester vitamin D levels $<20 \mathrm{ng} / \mathrm{ml}$ and 1 female had levels between $20-30 \mathrm{ng} / \mathrm{ml}$. The mean $1^{\text {st }}$ trimester vitamin $\mathrm{D}$ level in these 23 females was significantly lower compared to females who had term babies $(12.43 \pm 3.13 \mathrm{ng} / \mathrm{ml}$ vs. $19.40 \pm 7.10 \mathrm{ng} / \mathrm{ml}, \mathrm{P}=0.0001)$. Similarly, mean $3^{\text {rd }}$ trimester vitamin D level was also significantly lower $(14.43 \pm 3.74 \mathrm{ng} / \mathrm{ml}$ vs. $27.41 \pm 7.53 \mathrm{ng} / \mathrm{ml})$. Thus, females who had preterm birth had much lower $1^{\text {st }}$ and $3^{\text {rd }}$ trimester vitamin $D$ levels as compared to rest of the females.

A Japanese retrospective study found mothers with threatened premature delivery had significantly lower $25-0$ HD levels $(11.2 \pm 3.2$ $\mathrm{ng} / \mathrm{ml})$ than those in mothers with normal delivery $(15.6 \pm 5.1 \mathrm{ng} /$ $\mathrm{ml}$ ) [27]. Recently a multi centre study involving US cohort of twin pregnancies showed an independent association between maternal 25-hydroxyvitamin D concentrations at 24-28 weeks of gestation and preterm birth [28].

In our study, the mean birth weight in women who are supplemented with vitamin D is $2.82 \mathrm{~kg}$, which is statistically significant than women who were not supplemented. A systematic review and meta-analysis by Pérez-López et al. found that gestational vitamin D supplementation was associated with increased birth weight and birth length (Table 4) [29]. In a recently published study Gernand $\mathrm{AD}$ et al. also showed that mothers with $25(\mathrm{OH}) \mathrm{D}$ of $37.5 \mathrm{nmol} /$ liter or greater gave birth to newborns with $46 \mathrm{~g}$ higher compared with mothers with less than $37.5 \mathrm{nmol} /$ liter [30].

\section{Conclusion}

The present study concludes that there is high prevalence of vitamin D deficiency in pregnancy. Though India is a tropical country more than $90 \%$ of pregnant women are either deficient or insufficient. Vitamin D deficiency correlates with preeclampsia and preterm birth. There is significant increase in birth weight in women who were supplemented with vitamin D. Supplementation of vitamin D is safe and it increases vitamin D levels significantly in $3^{\text {rd }}$ trimester. Thus, this study emphasizes the need of screening of pregnant females for vitamin $\mathrm{D}$ deficiency and supplementation if required for better fetomaternal outcomes.

\section{References}

1. Holick MF, chen TC. Vitamin D deficiency; a worldwide problem with health consequences. Am JClinNutr. 2008; 87: 1080S-1086S.

2. Hollis BW, Wagner CL. Assessment of dietary vitamin $D$ requirements during pregnancy and lactation. Am J ClinNutr. 2004; 79: 717-726.
3. Lee JM, Smith JR, Philipp BL, Chen TC, Mathieu J, Holick MF. Vitamin D deficiency in a healthy group of mothers and newborn infants. ClinPediatr (Phila). 2007; 46: 42-44.

4. Bodnar LM, Simhan HN, Powers RW, Frank MP, Cooperstein E, Roberts JM. High prevalence of vitamin D insufficiency in black and white pregnant women residing in the northern United States and their neonates. J Nutr. 2007; 137: 447-452.

5. Dijkstra SH, van Beek A, Janssen JW, de VleeschouwerLH, Huysman WA, van den Akker EL. High prevalence of vitamin $D$ deficiency in newborn infants of high-risk mothers. Arch Dis Child. 2007; 92: 750-753.

6. Throne-Layman A, Fawazi WW. Vitamin D during pregnancy and maternal, neonatal and infant health outcomes: a systematic review and meta-analysis. Peadiatre Perinat Epidemiol. 2012; 260.

7. Holick MF, Binkley NC, Bischoff-Ferrari HA, Gordon CM, Hanley DA, Heaney $\mathrm{RP}$, et al. Evaluation, Treatment and prevention of vitamin D deficiency: An Endocrine society clinical practice guideline. Endocrinolmetab. 2011; 96: 1911-1930.

8. Bodnar LM,Cator JM, Roberts JM. Racial/ethnic differences in the monthly variation of preeclampsia incidence. Am J obstetGynecol. 2007; 196: 321325.

9. Seely EW. Calciotrophic hormones in preeclampsia, a renewal of interest. J Clin Endocrinol Metab. 2007; 92: 3402-3403.

10. Bodnar LM, CatorJM, Simhan HN, Holick MF, Powers RN, Roberts JM. Maternal Vitamin D deficiency increases the risk of preeclampsia. Clin Endocrinolmetab.2007; 92: 3517-3522.

11. Robinson $\mathrm{CJ}$, wagner $\mathrm{CI}$, Hollis BW, Baatz JE, Johnson DD. Maternal vitamin D and fetal growth in early onset preeclampsia. Am J Obstet Gynecol. 2011; 204: 556.e1-4.

12. Leffelar ER, Vrijkotte TG, van Eijsden M. Maternal early pregnancy vitamin D status in relation to fetal and neonatal growth:results of multi-ethnic Amsterdam Born children and their development cohort.Br J Nutr. 2010; 104: 108-117.

13. Morley R, Carlin JB, Pasco JA, Wark JD. Maternal 25-hydroxyvitamin D and parathyroid hormone concentrations and offspring birth size. JClin Endocrinol Metab. 2006; 91: 906-912.

14. Cockburn F, Belton IR, Purvis RJ, Giles MM, Brown JK, Turner TL, et al. Maternal vitamin intake and mineral metabolism in mothers and their newborn infants. BMJ. 1980; 281: 11-14.

15. Brooke OG, Brown IR, Bone CD, Carter ND, Cleeve HJ, Maxwell JD, et al. vitamin D supplements in pregnant Asian women: effects on calcium status and fetal growth. BMJ. 1980; 280: 751-754.

16. Vieth R, Chan PC, MacFarlane GD. Efficacy and safety of vitamin D3 intake exceeding the lowest observed adverse effect level. AM J ClinNutr. 2001; 73: $288-294$.

17. Heaney RP, Davies KM, Chen TC, Holick MF, Barger-Lux MJ. Human serum 25-hydroxycholecalciferol response to extended oral dosing with cholecalciferol. AM J ClinNutr. 2003; 77: 204-210.

18. Vitamin D; Screening and supplementation during pregnancy. Committee opinion no 495. American college of obstetrics and Gynaecologists obstetGynecol. 2011; 118: 197-198.

19. Sachan A, Gupta R, Das V, Agarwal A, Awasthi PK, Bhatia V. High prevalence of vitamin $D$ deficiency among pregnant women and their newborn in northern India.Am J Clin Nutr. 2005; 81: 1060-1064.

20. Jiang L, Xu J, Pan S, Xie E, Hu Z, Shen H. High prevalence of hypovitaminosis D among pregnant women in southeast China. Acta Paediatr. 2012; 101: e192-e194.

21. Shibata M, Suzuki A, Sekiya T, Sekiguchi S, Asano S, Udagawa $Y$, et al High prevalence of hypovitaminosis $D$ in pregnant Japanese women with threatened premature delivery. J. Bone Miner. Metab. 2011; 29: 615-620.

22. Choi R, Kim S, Yoo H, Cho YY, Kim SW, Chung JH, et al. High prevalence of vitamin D deficiency in pregnant Korean women . Nutrients. 2015; 7: 34273448. 
23. Sahu M, Bhatia V, Agarwal A, Rawat V, Saxena P, Pandey A, et al. Vitamin $D$ deficiency in rural girls and pregnant women despite abundant sunshine in northern India. Clin Endocrinol (oxf). 2009; 70: 680-684.

24. Marwaha RK, Tandon N, Chopra S, Agarwal N, Garg MK, Sharma B, et al. Vitamin D status in pregnant Indian women across trimesters and different seasons and its correlation with neonatal 25- hydroxyvitamin D levels. $\mathrm{Br} \mathrm{J}$ Nutr. 2011; 106: 1383-1389.

25. De-Regil LM, Palacios C, Ansary A, Kulier R, Pena-Rosas JP. Vitamin D supplementation for women during pregnancy. Chochrane Databasesyst Rev. 2012; 2: CD008873.

26. Barker AM, Haeri S, Camargo CA Jr, Espinalo JA, Stuebe AM. A nested casecontrol study of midgestation vitamin $D$ deficiency and risk of preeclampsia. $J$ Clin Endocrinol Metab. 2010; 95: 5105-5109.

27. Shibata M, Suzuki A, Sekiya T, Sekiguchi S, Asano S, et al. High prevalence of hypovitaminosis $D$ in pregnant Japanese women with threatened premature delivery. J Bone Miner Metab. 2011; 29: 615-620.
28. Bodnar LM, Rouse DJ, MomirovaV, Peaceman AM, Sciscione A, Spongy CY, et al. Maternal 25-hydroxyvitamin D and preterm birth in twin gestations. Obstet Gynecol. 2013; 122: 91-98.

29. Perez-Lopez FR, Pasupuleti V, Mezones-Holguin E, Benites-Zapata VA, Thota P, Deshpande A, et al. "Effect of vitamin D supplementation during pregnancy on maternal and neonatal outcomes:a systematic review and meta-analysis of randomised controlled trials,"Fertility and sterility. 2015; 103 : 1278-1288.e4.

30. Gernand AD, Simhan HN, Klebanoff MA, Bodnar LM. Maternal serum 25-hydroxy vitamin $\mathrm{D}$ and measures of newborn and placental weight in a US multicentre cohort study. J Clin Endocrinol Metab. 2013; 98: 398-404.
Ann Nutr Disord \& Ther - Volume 4 Issue $1-2017$

ISSN : 2381-8891 | www.austinpublishing group.com

Swapna et al. (C) All rights are reserved
Citation: Vasundhara K, Swapna R, Prasannalatha A and Shruti K. Vitamin D Supplementation in Pregnancy and Its Correlation with Fetomaternal Outcome. Ann Nutr Disord \& Ther. 2017; 4(1): 1037. 